\title{
Hepatoprotective and antioxidant activity of Murraya Koenigii leaves extract against paracetamol induced hepatotoxicity in Rats
}

\author{
Kartik J. Salwe ${ }^{1 *}$, Mirunalini R. ${ }^{1}$, Jervin Mano ${ }^{2}$, K. Manimekalai ${ }^{1}$
}

${ }^{1}$ Department of Pharmacology, Mahatma Gandhi Medical College and Research Institute, Sri Balaji Vidyapeeth, Pillaiyarkuppam, Puducherry, India

${ }^{2}$ Scientific Project Manager, Abbott Healthcare Pvt. Ltd, Mumbai, Maharashtra, India

Received: 22 April 2017

Accepted: 01 May 2017

*Correspondence to:

Dr. Kartik J. Salwe,

Email: kartiksalwe@gmail.com

Copyright: (C) the author(s), publisher and licensee Medip Academy. This is an openaccess article distributed under the terms of the Creative Commons Attribution NonCommercial License, which permits unrestricted noncommercial use, distribution, and reproduction in any medium, provided the original work is properly cited.

\begin{abstract}
Background: Many pharmacological substances are known to cause hepatic injuries and paracetamol is one out of them. This study was carried out to investigate the hepatoprotective and antioxidant activity of hydroalcoholic extract of Murraya koenigii leaves in paracetamol induced hepatotoxicity in Rats.

Methods: Experimental animal used in this study were 30 healthy male albino Wistar rats of 10 to 12 wks weighing $180 \pm 20 \mathrm{~g}$. After acclimatization for a period of one week, the rats were randomized into five groups of six rats each. Safety profile and dose selection of extract was evaluated using acute toxicity studies. Five groups named as Normal control, Paracetamol induced hepatotoxicity, Murraya koenigii leaves extract $100 \mathrm{mg} / \mathrm{kg}$ bw, Murraya koenigii leaves extract $200 \mathrm{mg} / \mathrm{kg}$ bw and Silymarin group respectively. The doses of drugs and plant extract was calculated based on the body weight of each animal and administered orally for 7 days. On $8^{\text {th }}$ day rats were sacrificed and blood samples were collected by cardiac puncture for biochemical estimation of biochemical parameters. Then abdomen was opened to get liver sample for antioxidant activity and histopathology.
\end{abstract}

Results: Acute toxicity studies showed the non-toxic nature of Murraya koenigii leaves extract upto dose of $2000 \mathrm{mg} / \mathrm{kg}$ body weight. Murraya koenigii leaves extract in both doses showed a significant drop in the mean levels of AST, ALT, ALP, TP and TB when compared with toxic control group. The higher dose was found better than lower dose. Silymarin was found better than both the doses. Murraya koenigii leaves extract in both doses significantly reduced the TBARS level when compared to toxic control group. The activities of GSH, SOD and CAT in liver were significantly lower in Paracetamol induced hepatotoxicity rats compared to control rats. Murraya koenigii leaves extract at both doses showed a significant increase in GSH, SOD and CAT. The higher dose was found better than lower dose. Silymarin was found better than both the doses. Histopathology of Liver biopsy with higher dose of Murraya koenigii leaves extract showed reduced periportal inflammation with mild hepatic venous congestion and Silymarin treated rats showed no periportal inflammation with mild congestion in few central veins.

Conclusions: Murraya koenigii leaves extract possesses significant Hepatoprotective property; this may be due to antioxidant activity. Further studies are required to determine the exact mechanism.

Keywords: Antioxidant, Hepatoprotective, Murraya koenigii, Paracetamol, Silymarin

\section{INTRODUCTION}

Liver is the major primary site for Biotransformation of drugs. Being the major drug detoxifying organ of the body it is continuously exposed to xenobiotics and drugs. ${ }^{1}$ Usually the prescribed drugs are tolerated but overdose is the most common cause of drug induced liver disease. Hepatotoxicity is one of the very common ailment resulting into serious debility even mortality. ${ }^{2}$ Most of the hepatotoxic chemicals damage liver cells 
mainly by inducing lipid peroxidation and other oxidative damage. ${ }^{3}$

Paracetamol is one of the most commonly used nonnarcotic, analgesic-antipyretic agent with negligible antiinflammatory activity. It is indicated in fever and mild to moderate pain such as headache and myalgia. ${ }^{4}$ In therapeutic dose it is quite safe and well tolerated. However, toxic doses of paracetamol cause severe hepatotoxicity that leads to liver failure in both human and animals. 5,6 Paracetamol induced hepatotoxicity is used as a test model to screen indigenous drugs.

In view of severe undesirable side effects of synthetic drugs, the attention was focused on finding out safer and potent hepatoprotective drug. Many traditional herbal medicines are claimed to possess hepatoprotective activity. 7,8

Murraya koenigii, commonly known as Curry patta is one such highly valued plant used for seasoning in Indian cooking. This plant has wide array of properties that include anti diarrhoeal, antimicrobial, anti-inflammatory and anti-ulcer activities. ${ }^{9,10}$

However, there are only few scientific studies on hepatoprotective activity in the literature. Hence, the present study was planned to evaluate the hepatoprotective activity of hydroalcoholic extract of Murraya koenigii leaves in Rats.

\section{METHODS}

\section{Collection and identification of plant materials}

Murraya koenigii leaves were purchased from the local vegetable market in Puducherry and then authenticated by a botanist. The leaves were carefully cleaned, shadedried, powdered and stored in an air tight container until the extraction procedure.

\section{Preparation of extract}

Hydroalcoholic extract was prepared by the Soxhletion method. The powder of Murraya koenigii was extracted with $70 \%$ ethanol and $30 \%$ distilled water (i.e. hydroalcoholic extract) using soxhlet apparatus $\left(50-55^{\circ} \mathrm{C}\right)$ for three days. ${ }^{11}$ The extract was concentrated in a ventilated oven at $45^{\circ} \mathrm{C}$ for $24 \mathrm{~h}$. $45 \mathrm{~g}$ of dried powder yielded an extract of about $7 \mathrm{~g}$ which was dark brown in color. It was dissolved in $0.5 \%$ Carboxy-methyl-cellulose (CMC) before administering it to the experimental animals.

\section{Drugs and chemicals}

Silymarin and Paracetamol from Microlabs, Bangalore was procured from local medical store.2-thiobarbituric acid and Ellman's reagent was purchased from Sigma Aldrich, Bangalore. All other solvents and chemicals of analytical grade were used and obtained from SD fine chemicals, Mumbai.

\section{Animals}

30 healthy male albino Wistar rats weighing $180 \pm 20 \mathrm{~g}$ and 10 to 12 weeks of age were used in this study. They were procured from King's Institute, Guindy, Chennai and housed in central animal house, Mahatma Gandhi Medical College and Research Institute, Pillaiyarkuppam, Puducherry. The animals were kept in polypropylene cages, with dry paddy husk bedding and covered with stainless steel mesh lid. The environment of the room was maintained on a 12-hour light/dark cycle at a constant room temperature of $26 \pm 2{ }^{\circ} \mathrm{C}$ and relative humidity of 45 $55 \%$. The rats had free access to standard rat chow diet and water ad libitum. The rats were acclimatized to the surroundings for 2 weeks prior to the experiment.

The animals were cared as per the guidelines of Committee for the Purpose of Control and Supervision of Experiments on Animals (CPCSEA), New Delhi, India.

\section{Acute toxicity study and dose selection}

Healthy adult male albino Wistar rats were used for this study. Accordingly, the test doses of both extracts were selected by trial and error. Pilot study was done using three doses $500 \mathrm{mg} / \mathrm{kg}$ body weight, $1000 \mathrm{mg} / \mathrm{kg}$ body weight and $2000 \mathrm{mg} / \mathrm{kg}$ body weight of the Hydroalcoholic extract of Murraya koenigii leaves. The animals were observed continuously for $4 \mathrm{~h}$ and then occasionally overnight. Animals were observed for tremors, clonic convulsions, tonic extensions, catatonia, spasticity, opisthotonus, ataxia, sedation, ptosis, respiration. After a period of 24 and $72 \mathrm{~h}$ they were observed for any mortality. ${ }^{12}$

\section{Experimental design}

A total number of 30 rats were used for the study. After acclimatization for a period of one week, the rats were numbered and were randomized into five groups of six rats each. Randomization was done by online based randomization tool based on the numbers given to individual rats.

Group 1 received $0.5 \%$ carboxy methyl cellulose $1 \mathrm{ml} / \mathrm{kg}$ for 7 days and served as Normal control. Group 2 received $0.5 \%$ carboxy methyl cellulose $1 \mathrm{ml} / \mathrm{kg}$ for 7 days followed by intoxication with single dose of Paracetamol at a dose of $2 \mathrm{~g} / \mathrm{kg}$ orally. Group 3 and Group 4 were pretreated with Murraya koenigii leaves extract at a dose of $100 \mathrm{mg} / \mathrm{kg}$ and $200 \mathrm{mg} / \mathrm{kg}$ orally respectively for 7 days followed by intoxication with single dose of Paracetamol. Group 5 were pretreated with Silymarin $25 \mathrm{mg} / \mathrm{kg}$ orally for 7 days followed by intoxication with single dose of Paracetamol. 
The doses of drugs and plant extract was calculated based on the body weight of each animal, suspended in $0.5 \%$ CMC and the respective volume was administered orally with the help of syringe and gavage needle.

The doses of Paracetamol and Silymarin and duration of the treatment were calculated from previous studies. ${ }^{13}$

\section{Euthanasia}

The rats were fasted overnight after the last dosing. On the $8^{\text {th }}$ day the rats were sacrificed by overdose of sodium pentobarbital $150 \mathrm{mg} / \mathrm{kg}$ i.p.

\section{Blood sample collection}

The blood samples were collected by cardiac puncture using a 20gauge needle as described by McClure et al, in labelled centrifuging tubes and allowed to clot for $45 \mathrm{~min}$ at room temperature. ${ }^{14}$ The samples were centrifuged at $2500 \mathrm{rpm}$ for $15 \mathrm{~min}$. The separated serum was sent immediately for biochemical analysis.

\section{Specimen collection}

The abdominal cavity was opened with a long midline incision, the liver was harvested and washed with normal saline and blotted with a filter paper. A small portion of the liver was transferred to individually labelled containers with $1.15 \% \mathrm{KCl}$ and stored in a deep freezer. The rest of the liver was carefully transferred to containers with $10 \%$ formalin and marked for histopathology.

\section{Biochemical estimation}

The separated serum was used for the estimation of biochemical parameters. The liver transaminases, AST and ALT were measured according to the method of Rietman and Frankel. ${ }^{15}$ ALP was measured according to the method of Kind and King. ${ }^{16}$ Total protein (TP) levels were determined by Lowry protein assay. ${ }^{17}$ Estimation of Total bilirubin (TB) were followed by modified DMSO method. ${ }^{18}$

\section{In vivo antioxidant activity}

The antioxidant potential of the plant extract was tested using three tests: TBARS assay, Reduced GSH, Catalase and SOD activity. The test was done in Research laboratory of Department of Biochemistry, Mahatma Gandhi Medical College and Research Institute, Puducherry.

$1 \mathrm{~g}$ of the liver tissue was weighed and homogenised in 9 $\mathrm{ml}$ of $1.15 \% \mathrm{KCl}$ using a Homogenizer. After homogenisation, the liver homogenate was kept in a freezer until it got frozen, then brought to room temperature until it liquefied. This procedure was repeated for two freeze-thaw cycles. Then the liver homogenate was centrifuged at $3000 \mathrm{rpm}$ at $4^{\circ} \mathrm{C}$ for 30 min. The supernatant of the liver homogenate was separated and used for assays.

The levels of Thiobarbituritic acid reactive substances (TBARS) in tissues were estimated by the method of Ohkawa et al. ${ }^{19}$ The activity of GSH and Catalase was determined by the method of Sinha. ${ }^{20.21}$ Superoxide dismutase (SOD) activity was determined by the method of Kakkar et al. ${ }^{22}$

\section{Histopathological observation}

Conventional techniques of paraffin-wax sectioning and haematoxylin-eosin staining were used for histological studies. Pieces of liver tissues were fixed in $10 \%$ neutral buffered formalin for $24 \mathrm{~h}$. Following fixation, bits were taken from representative area of liver tissue, processed through an ascending series of ethanol, cleared in xylene and impregnated with wax at $57^{\circ} \mathrm{C}$ then embedded in paraffin block. Sections of $5 \mu \mathrm{m}$ were cut and stained with haematoxylin and eosin, then examined in the Adeltaoptec microscope and the microphotographs were taken using Adelta vision HD camera. ${ }^{23}$

\section{Statistical analysis}

Collected data entered and analyzed using SPSS. Inc statistical software version 17.0. Results were expressed as Mean \pm SD. Statistical analysis was done using analysis of variance followed by Turkey's Post hoc test. P value $<0.05$ was considered as statistically significant.

\section{RESULTS}

\section{Acute toxicity study of Murraya koenigii leaves extract in rats}

Acute toxicity studies showed the non-toxic nature of the Murraya koenigii leaves extract upto dose of $2000 \mathrm{mg} / \mathrm{kg}$ body weight which is 10 times more than the dose used in the study. There was no mortality of any animals when observed for $72 \mathrm{hr}$. There was no lethality or any toxic reactions found at any of the doses selected until the end of the study period.

\section{Effect of Murraya koenigii leaves extract on serum biochemical parameters}

The serum levels of aspartate aminotransferase (AST), alanine aminotransferase (ALT) and alkaline phosphatase (ALP), total bilirubin was significantly increased and the levels of total protein were significantly decreased in paracetamol intoxicated rats when compared to normal control group (Table 1).

The group which received Murraya koenigii leaves extract at $100 \mathrm{mg} / \mathrm{kg}$ bw and $200 \mathrm{mg} / \mathrm{kg}$ bw showed a significant reduction in the mean levels of AST, ALT, ALP, TB and restoration of total protein levels towards 
normalcy when compared to paracetamol intoxicated group. The group which received higher dose $(200 \mathrm{mg} / \mathrm{kgbw})$ was found better than lower dose (100mg/kgbw). Standard drug Silymarin was found better than Low dose but there was no significant difference between high dose of Murraya koenigii leaves extract and Silymarin (Table 1).

\section{Effect of Murraya koenigii leaves extract on hepatic oxidative stress parameters}

In Paracetamol induced hepatotoxicity group there was marked increase in the TBARS levels compared to control rats. Administration of Murraya koenigii leaves extract at both doses significantly reduced the TBARS levels when compared to paracetamol intoxicated group.
The activities of GSH, SOD and CAT in liver were significantly lower in Paracetamol induced hepatotoxicity rats compared to control rats.

Administration of Murraya koenigii leaves extract at both doses showed a significant increase in GSH, SOD and CAT activity when compared to paracetamol intoxicated group.

Treatment with standard drug Silymarin showed a significant reduction in the mean TBARS levels and significant increase in activities of GSH, SOD and CAT in liver when compared to paracetamol intoxicated group and Murraya koenigii leaves extract at lower dose but there was no significant difference between high dose of Murraya koenigii leaves extract and Silymarin (Table 2).

Table 1: Effect of Murraya koenigii leaves extract on biochemical parameters in Paracetamol induced hepatic injury in rats.

\begin{tabular}{|llllll|} 
& SGOT (AST) IU/I & SGPT (ALT) IU/l & ALP (IU/l) & $\begin{array}{l}\text { Total Bilurubin } \\
\text { (mg/dl) }\end{array}$ & TP (mg/dl) \\
\hline Normal & $49.5 \pm 1.8$ & $35.67 \pm 2.46$ & $97.5 \pm 3.4$ & $0.25 \pm 0.03$ & $6.92 \pm 0.2 \mathrm{~ns}$ \\
\hline Paracetamol (PCM) & $156.17 \pm 2.5^{*}$ & $251.17 \pm 6.09^{*}$ & $215.83 \pm 6.44^{*}$ & $2.27 \pm 0.08^{*}$ & $3.78 \pm 0.15^{*}$ \\
\hline MKLE 100+PCM & $127.91 \pm 2.71^{* *}$ & $181.71 \pm 2.92^{* *}$ & $175.65 \pm 3.71^{* *}$ & $1.97 \pm 0.23^{* *}$ & $5.55 \pm 0.21^{* *}$ \\
\hline MKLE 200+PCM & $99.45 \pm 3.33^{* *}$ & $143.15 \pm 2.96^{* *}$ & $139.65 \pm 2.74^{* *}$ & $1.04 \pm 0.08^{* *}$ & $6.14 \pm 0.2^{* *}$ \\
\hline Silymarin+PCM & $93.83 \pm 2.21^{* *}$ & $141.67 \pm 2.73^{* *}$ & $138.83 \pm 4.51^{* *}$ & $0.97 \pm 0.14^{* *}$ & $6.03 \pm 0.09^{* *}$ \\
\hline
\end{tabular}

Values are expressed as Mean \pm SEM with $\mathrm{n}=6$; One way ANOVA followed by Tukey's post hoc test. *p<0.05 when Normal control group compared to PCM treated group; **p<0.05 when PCM treated group compared to MKLE $100 \mathrm{mg} / \mathrm{kg}$ bw, MKLE $200 \mathrm{mg} / \mathrm{kg} b$ and Standard drug Silymarin

Table 2: Effect of Murraya koenigii leaves extracts on TBARS, SOD and Catalase in Paracetamol induced hepatotoxicity in rats $(n=6)$.

\begin{tabular}{|lllll|}
\hline & $\begin{array}{l}\text { TBARS } \\
(\mathbf{m m o} / \mathbf{1 0 0 g})\end{array}$ & $\begin{array}{l}\text { GSH } \\
(\text { Umin/mg Protein) }\end{array}$ & $\begin{array}{l}\text { CAT } \\
\text { (Umin/mg Protein) }\end{array}$ & $\begin{array}{l}\text { SOD } \\
\text { (Umin/mg Protein) }\end{array}$ \\
\hline Normal & $0.91 \pm 0.37$ & $4.08 \pm 0.09$ & $339.5 \pm 1.01$ & $3.25 \pm 0.25$ \\
\hline Paracetamol (PCM) & $3.12 \pm 0.07^{*}$ & $1.76 \pm 0.08^{*}$ & $287.55 \pm 0.64^{*}$ & $1.97 \pm 0.15^{*}$ \\
\hline MKLE 100+PCM & $1.99 \pm 0.06^{* *}$ & $2.73 \pm 0.07^{* *}$ & $300.38 \pm 1.26^{* *}$ & $2.13 \pm 0.23^{* *}$ \\
\hline MKLE 200+PCM & $1.05 \pm 0.04^{* *}$ & $3.92 \pm 0.06^{* *}$ & $337.87 \pm 0.95^{* *}$ & $2.49 \pm 0.31^{* *}$ \\
\hline Silymarin+PCM & $1.22 \pm 0.03^{* *}$ & $3.91 \pm 0.07^{* *}$ & $334.55 \pm 1.86^{* *}$ & $2.87 \pm 0.28^{* *}$ \\
\hline
\end{tabular}

Values are expressed as Mean \pm SEM with $\mathrm{n}=6$; One way ANOVA followed by Tukey's post hoc test. *p<0.05 when Normal control group compared to PCM treated group; **p<0.05 when PCM treated group compared to MKLE $100 \mathrm{mg} / \mathrm{kg}$ bw, MKLE $200 \mathrm{mg} / \mathrm{kg}$ b and Standard drug Silymarin

\section{Effect of oral administration of hydroalcoholic extract of Murraya koenigii leaves on histopathological changes in liver}

Liver biopsy section showed normal lobular architecture and normal hepatic cells (Figure 1).

Whereas rats intoxicated with paracetamol showed mild distortion of hepatic architecture, central venous congestion with periportal chronic lymphocytic infiltration (Figure 2).
Rats which received Murraya koenigii leaves extract at $100 \mathrm{mg} / \mathrm{kg}$ bw showed central venous congestion with periportal chronic lymphocytic infiltration (Figure 3).

Rats which received Murraya koenigii leaves extract at $200 \mathrm{mg} / \mathrm{kg}$ bw showed reduced periportal inflammation with mild hepatic venous congestion (Figure 4).

Silymarin treated rats showed no periportal inflammation with mild congestion in few central veins (Figure 5). 


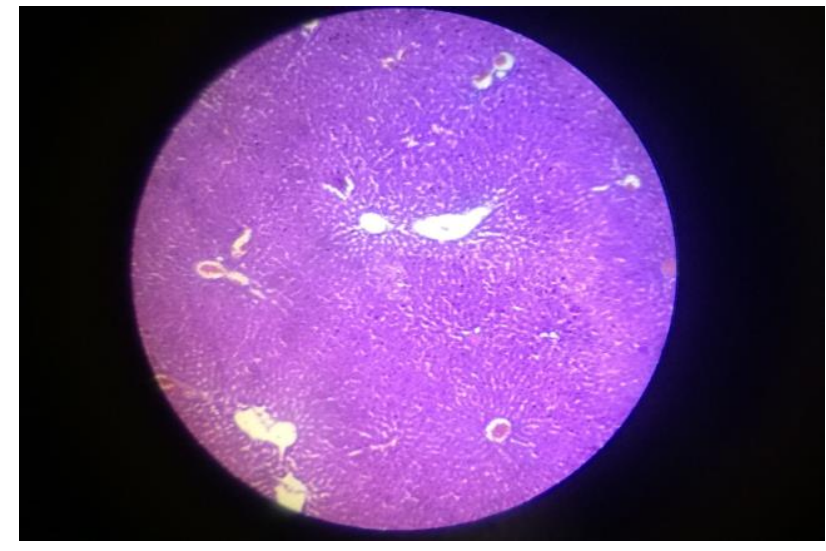

Figure 1: Liver biopsy section stained with hematoxylin and eosin (H and $\mathrm{E}$ ) showing normal histology of liver in normal control group (5X magnification).

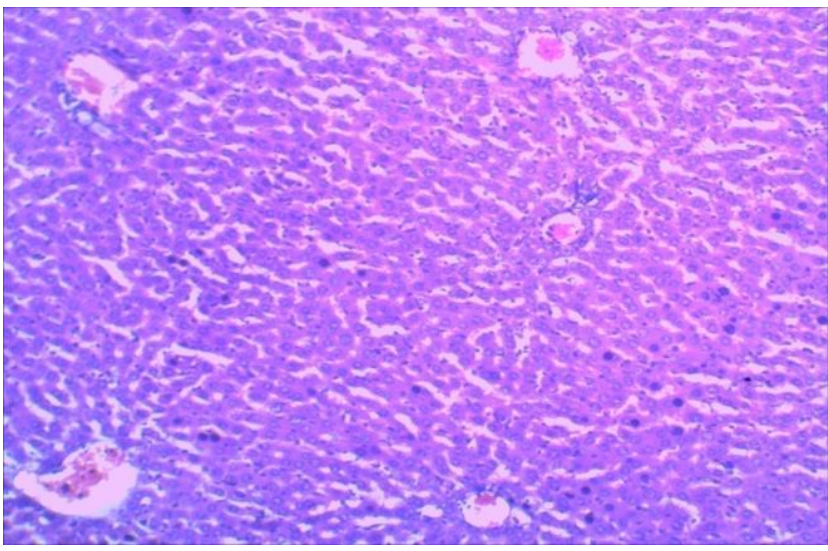

Figure 2: Liver biopsy section stained with hematoxylin and eosin ( $\mathrm{H}$ and $\mathrm{E}$ ) in rats intoxicated with paracetamol showing mild distortion of hepatic architecture, central venous congestion with periportal chronic lymphocytic infiltration (40X magnification).

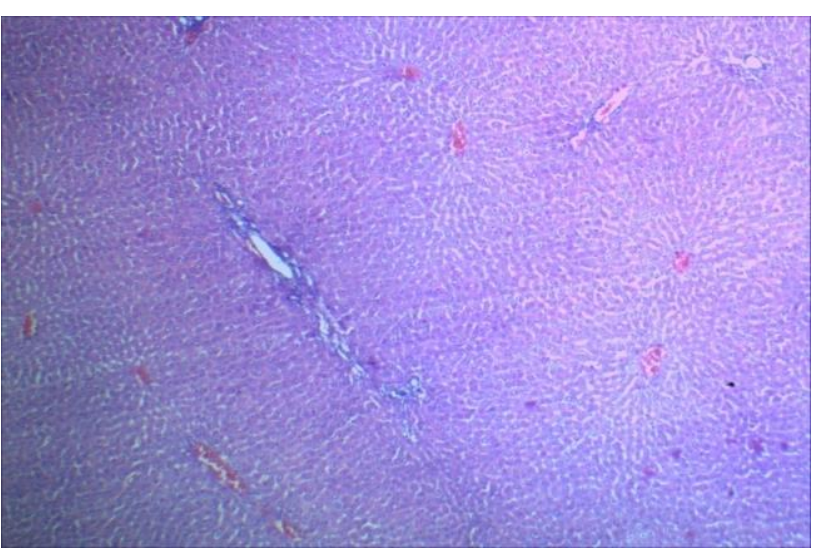

Figure 3: Liver biopsy section stained with hematoxylin and eosin $(\mathrm{H}$ and $\mathrm{E})$ in rats treated with Murraya koenigii leaves extract at $100 \mathrm{mg} / \mathrm{kg}$ bw, showing central venous congestion with periportal chronic lymphocytic infiltration (10X magnification).

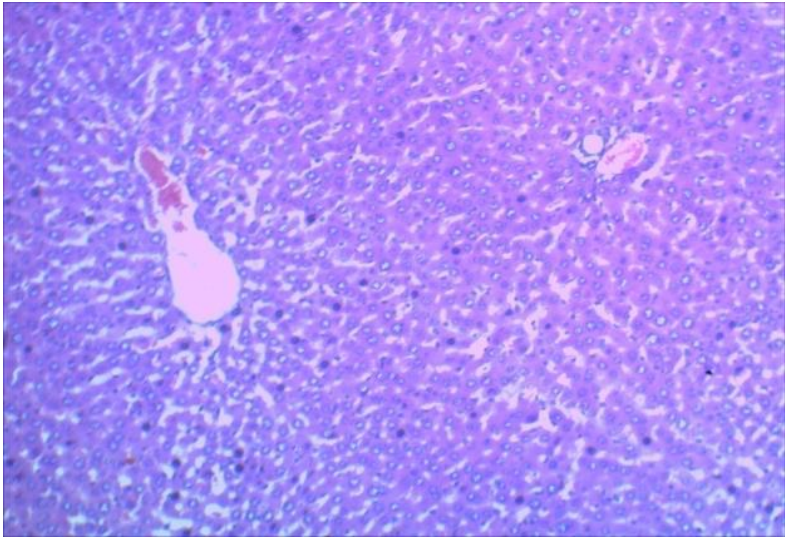

Figure 4: Liver biopsy section stained with hematoxylin and eosin $(\mathrm{H}$ and $\mathrm{E})$ in rats received Murraya koenigii leaves extract at $200 \mathrm{mg} / \mathrm{kg}$ bw, showing reduced periportal inflammation with mild hepatic venous congestion (40X magnification).

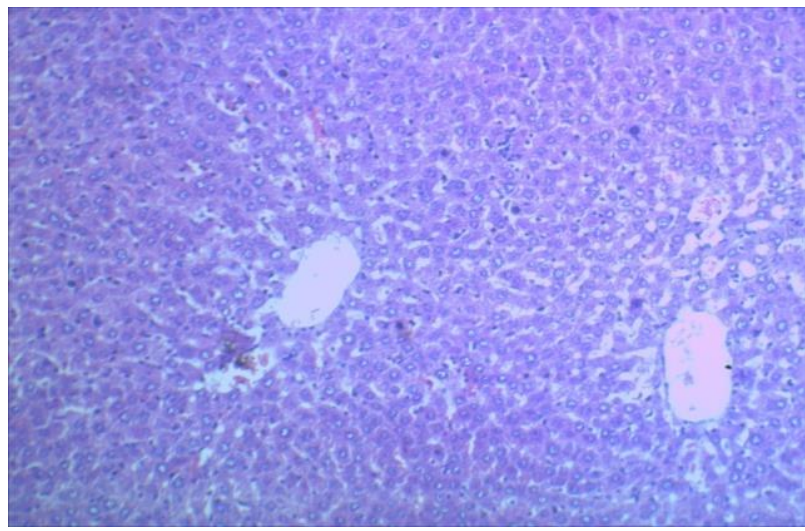

Figure 5: Liver biopsy section stained with hematoxylin and eosin $(\mathrm{H}$ and $\mathrm{E})$ in rats treated with Silymarin showing no periportal inflammation with mild congestion in few central veins

(40X magnification).

\section{DISCUSSION}

The study was carried out to evaluate the hepatoprotective and antioxidant activity of hydroalcoholic extract of Murraya koenigii leaves in paracetamol induced hepatotoxicity in Male Wistar Albino Rats.

The liver is a major target organ for toxicity from xenobiotics and drugs because it is the primary site for the biotransformation. Drug induced liver disorders occurred frequently and can be life threatening. Many chemicals and drugs are known to cause hepatic injuries and paracetamol is one of them.

Paracetamol is a non-steroidal anti-inflammatory drug (NSAID), most commonly indicated in fever and mild to moderate pain like headache and myalgia. ${ }^{4}$ It is one of the safest NSAID in therapeutic dose and is well tolerated. 
However, toxic doses of paracetamol cause severe hepatotoxicity characterized by abnormality of hepatic function and degeneration, necrosis or apoptosis of hepatocytes that leads to liver failure in both human and animals. ${ }^{5,6}$ Paracetamol has been taken as test model to screen the anti-hepatotoxicity of indigenous drugs. ${ }^{24}$

Drug-induced liver damage (hepatotoxicity) results from complex sequence of events, not from paracetamol itself, but generally accepted that its $\mathrm{P}_{450}$-dependent bioactivation to one of its metabolites N-acetyl-pbenzoquinoneimine (NAPQI) which is a main cause of potentially fulminant hepatic necrosis. ${ }^{25,26}$ NAPQI decreases the liver's natural antioxidant glutathione and directly damages cells in the liver, leading to liver failure. ${ }^{27,28} \quad \mathrm{~N}$-acetyl-pbenzoquinoneimine (NAPQI) depletes glutathione causing peroxidative degradation of lipid membrane of the adipose tissue, which leads to leakage of serum marker enzymes. ${ }^{29}$

The elevated levels of serum marker enzymes SGOT and SGPT are indicative of cellular leakage and loss of functional integrity of cellular membrane in liver. Among the two, SGPT is a better index of liver injury, since SGPT catalyses the conversion of alanine to pyruvate and glutamate, and is released in a similar manner, thus liver SGPT represents $90 \%$ of total enzyme present in the body. ${ }^{30,31}$ ALP activities on the other hand are related to functioning of hepatocytes, its increase in serum is due to increased synthesis in the presence of increased biliary pressure. ${ }^{32,33}$

We have noted Murraya koenigii leaves extract at both doses showed a significant drop in the mean levels of AST, ALT and ALP when compared with toxic control group. This suggests that the Murraya koenigii leaves extract help to protect the integrity of plasma membrane as well as helped in healing the hepatic tissue damage against paracetamol induced leakage of marker enzymes in circulation.

Hypoalbuminaemia and decline in total protein content is a useful index of the severity of cellular dysfunction in chronic liver diseases. In this study, we have noted that the group receiving Murraya koenigii leaves extract showed a significant drop in the mean levels of TB and increase TP in dose dependent manner when compared to toxic control group though not better than Silymarin. This may be due to stimulation of protein synthesis as a contributory hepatoprotective mechanism, which accelerates the regeneration process and the production of liver cells. ${ }^{34}$

The increase in TBARS content is indicative of enhancement of lipid peroxidation which leads to tissue damage and a failure of enzymatic antioxidant defense mechanisms to prevent formation of excessive free radicals. ${ }^{35,36}$ To balance oxidative stress living tissues maintains innate antioxidants such as glutathione peroxidase and enzymes superoxide dismutase (SOD), catalase (CAT). They are most important enzymes in the enzymatic antioxidant defences system, which scavenges the superoxide anion hydrogen peroxide and oxygen, hence diminishing the toxic effect caused by these radicals. $^{37,38} \mathrm{~A}$ reduction in the activities of these enzymes is associated with the accumulation of highly reactive free radicals, leading to deleterious effects such as loss of integrity and function of cell membranes.

In the paracetamol intoxicated group TBARS level was significantly increased and the activities of glutathione, SOD and CAT were significantly decreased when compared with the control group. This may be largely due to lipid peroxidation due to increased free radical production caused by administration of paracetamol. Treatment with Murraya koenigii leaves extract significantly decreased TBARS levels and significantly increased the activities of glutathione, SOD and CAT in dose dependent manner hence, the mechanism of hepatoprotection by Murraya koenigii leaves extract may be due to its antioxidant property.

Histopathology of Liver biopsy tissues showed mild distortion of hepatic architecture, central venous congestion with periportal chronic lymphocytic infiltration with paracetamol. Murraya koenigii leaves extract treated group showed reduced periportal inflammation with mild hepatic venous congestion. Silymarin treated rats showed no periportal inflammation with mild congestion in few central veins. This is evident for the hepatoprotective nature of the plant extract.

The hepatoprotective and antioxidant effect of Murraya koenigii could be due to phytochemical tannins and carbazole alkaloids present in the leaves extract which offers hepatic protection and prevent the oxidative stress induced by free radicals damage by its antioxidant potential. ${ }^{39,40,41}$

Purification of Murraya koenigii extracts to identify the active constituents may yield production of hepatoprotective agent.

\section{CONCLUSION}

This study shows the hepatoprotective property of Murraya koenigii leaves extract in paracetamol induced oxidative stress and hepatotoxicity in rats. The study correlated the hepatoprotective activity of Murraya koenigii leaves may be due to free radical-scavenging and antioxidant activities which might be attributed to the presence of tannins and carbazole in the extract. Further research is required in this point of view before human use.

\section{ACKNOWLEDGEMENTS}

Authors are enormously thankful to Dr. Vaishali Kotasthane Assistant professor, Department of Pathology for her help in histopathological observations in study. 
We are also thankful for the help of technicians and attenders of Pharmacology and Pathology Departments.

Funding: Funding sources from Sri Balaji Vidyapeeth, Puducherry

Conflict of interest: None declared

Ethical approval: The study was approved by the Institutional Animal Ethics Committee, Mahatma Gandhi Medical College and Research Institute (Ref No: A/IAEC/MG/2014)

\section{REFERENCES}

1. Preussmann R. Hepatocarcinogens as potential risk for human liver cancer. In: Remmer H, Bolt HM, Bannasch P. Primary liver tumors. Lancaster: MTP Press; 1978:11-29.

2. Patel RK, Patel MM, Patel MP, Kanzaria NR, Vaghela KR, Patel NJ. Hepatoprotective activity of Moringa olerifera Lam fruit on isolated rat hepatocytes. Pheog Mag. 2008;4:118-23.

3. Chattopadhyay RR. Possible mechanism of hepatoprotective activity of Azadirachta indica leaf extract. J Ethnopharmacol. 2003;89:217-9.

4. Sharma HL, Sharma KK. Principles of Pharmacology, $3^{\text {rd }}$ Ed. Hyderabad, Paras Medical Publishers; 2016:370-371.

5. Masubuchi Y, Suda, C, Horie T. Involvement of mitochondrial permeability transition in acetaminophen induced liver injury in mice. Journal of Hepatology. 2005;(42):110-6.

6. Kaplovitz N. Idiosyncratic drug hepatotoxicity. Nature Reviews. 2005;(4):489-99.

7. Chatterjee TK. Medicinal plants with hepatoprotective properties. In: Herbal Options. $3^{\text {rd }}$ Ed. Calcutta Books and Allied (P) Ltd; 2000:135.

8. Rachehh MA, Yadav PN, Cokani RH, Jain SM. Antiinflammatory activity of Benincasa hispid fruit. Int J Phar Biosci. 2011;2:98-106.

9. Prajapati ND, Purohit, SS, Sharma AK, Kumar TA., Handbook of Medicinal Plants, Agrobios, Jodhpur; 2003:352-353

10. Handral HK, Jha PK, Shruthi SD. Pharmacognostic and Phytochemical studies on the leaves of Murraya koenigii (L) Spreng. Pharmacophore. 2010;1(3):2318.

11. Nikhal SB, Dambe PA, Ghongade DB, Goupale DC. Hydroalcoholic extraction of Mangifera indica (leaves) by Soxhletion. International Journal of Pharmaceutical Sciences. 2010;2(1):30-2.

12. Salwe KJ, Sachdev DO, Bahurupi Y, Kumarappan M. Evaluation of antidiabetic, hypolipedimic and antioxidant activity of hydroalcoholic extract of leaves and fruit peel of Punica granatum in male Wistar albino rats. $\mathrm{J}$ of Nat Sci, Biol Med. 2015;6(1):56-62.

13. Chattopadhyay RR. Possible mechanism of hepatoprotective activity of Azadirachta indica leaf extract: part II. J Ethnopharmacol. 2003;89(2-3):2179.
14. McClure DE. Clinical pathology and sample collection in the laboratory rodent. Vet Clin North Am Exot Anim Pr. 1999;2(3):565-90.

15. Reitman S, Frankel S. In vitro determination of transaminase activity in serum. Am J Clin Pathol. 1957;28:56-64.

16. Kind PRN, King EJ. Estimation of Plasma Phosphatase by Determination of Hydrolysed Phenol with Amino-antipyrine. J Clin Pathol. 1954;7(4):3226.

17. Lowry OH, Rosebrough NJ, Farr AL, Randall RJ. Protein measurement with the Folin phenol reagent. J Biol Chem. 1951;193(1):265-75.

18. Helga Tait Malloy KAE. The Determination of Bilirubin with the Photoelectric Colorimeter. J Biol Chem. 1937;119(2):481-90.

19. Ohkawa H, Ohishi N, Yagi K. Assay for lipid peroxides in animal tissues by thiobarbituric acid reaction. Anal Biochem. 1979;95(2):351-8.

20. Ellman GL. Tissue sulphydryl groups. Arch Biochem Biophys. 1959;(82):70-77.

21. Aebi H. Catalase. In: Bergmeyer HV, editor. Methods in enzymatic analysis. New York: Acadamic press. 1974;2:674-84.

22. Kakkar P, Das B, Viswanathan PN. A modified spectrophotometric assay of superoxide dismutase. Indian J Biochem Biophys. 1984;(21):131-2.

23. Carleton HM, Drury RAB, Wallington EA. General staining procedures. In: Carleton's Histological technique. $5^{\text {th }}$ Ed. New York: Oxford University Press; 1980:147-148.

24. Reid AB, Kurten RC, McCullough SS, Brock RW, Hinson JA. Mechanisms of acetaminophen-induced hepatotoxicity: role of oxidative stress and mitochondrial permeability transition in freshly isolated mouse hepatocytes. $\mathrm{J}$ of Pharmacol Exp Ther. 2005;312:509-16.

25. Knight TR, Kurtz A, Bajt ML, Hinson JA, Jaeschke H. Vascular and hepatocellular peroxy nitrite formation during acetaminophen induced liver injury: Role of mitochondrial oxidant stress. Toxicol Sci. 2001;62:212-20.

26. Bailey B, Amre DK, Gaudreault P. Fulminant hepatic failure secondary to acetaminophen poisoning: a systematic review and meta-analysis of prognostic criteria determining the need for liver transplantation. Critical Care Medicine. 2003;(31):299-305.

27. Tripathi KD. Essentials of medical Pharmacology, $7^{\text {th }}$ Ed. New Delhi, Jaypee Brothers Medical Publishers; 2013:206-207.

28. Dai Y, Cederbaum AI. Cytotoxicity of acetaminophen in human cytochrome P4502E1transfected HepG2 cells. J of Pharmacol Exp Ther. 1995;273(3):1497-505.

29. Gopinathan S. Molecular mechanisms of liver injury induced by hepatotoxins. Eur J Biomed Pharmaceut Sci. 2016;3(11):229-37.

30. Achliya GS, Kotgale SG, Wadodkar AK, Dorle AK. Hepatoprotective activity of Panchgavya Grithain 
carbon tetrachloride induced hepatotoxicity in rats. Indian J Pharmacol. 2003;35:311.

31. Drotman RB, Lawhorn GT. Serum enzymes are indicators of chemical induced liver damage. Drug Chem Toxicol. 1978;1:163.

32. Moss DW, Butterworth PJ. Enzymology and medicine Pitman Medical, London; 1974:39.

33. Willianson EM, Okpako DT, Evans FJ. Selection, preparation and pharmacological evaluation of plant material, John Wiley: England; 1996:13.

34. Larsson RL, Ross D, Berlin T, Olsson LI, Moldeus P. Prostaglandin synthase catalyzed metabolic activation of phenetidine and acetaminophen by microsomes isolated from rabbit and human kidney. $\mathrm{J}$ Pharmacol Exp Ther. 1985;(235):475-80.

35. Nishigaki I, Kuttan R, Oku H, Ashoori F, Abe H, Yagi K. Suppressive effect of curcumin on lipid peroxidation induced in rats by carbon tetrachloride irradiation. J of Clin Biochem Nutri. 1992;(13):23-9.

36. Slater TF. Free radical mechanisms in tissue injury. Biochemical Journal. 1984;(222):1-15.

37. Comporti M, Maellaro E, Del Bello B, Casini AF Glutathione depletion, its effect on other antioxidant systems and hepatocellular damage. Xenobiotica. 1991;21:1067.
38. Rajmohan T, Anthony LL. Hepatoprotective and antioxidant effect of tender coconut water on carbon tetrachloride induced liver injury in rats. Indian $\mathrm{J}$ Biochem Biophys. 2003;40:354.

39. Desai SN, Patel DK, Devkar RV, Patel PV, Ramachandran AV. Hepatoprotective potential of polyphenol rich extract of Murraya koenigii L. An in vivo study. Food Chem Toxicol. 2012;50:310-4.

40. Shivashankara AR, Azmidah A, Haniadka R, Rai MP, Arora R, Baliga MS. Dietary agents in the prevention of alcohol-induced hepatotoxicity. Preclinical observations. Food Funct. 2012;3:101-9.

41. Sathaye S, Bagul Y, Gupta S, Kaur H, Redkar R. Hepatoprotective effects of aqueous leaf extract and crude isolates of Murraya koenigii against in vitro ethanol-induced hepatotoxicity model. Exp Toxicol Pathol. 2011;63:587-91.

Cite this article as: Salwe KJ, Mirunalini R, Mano J, Manimekalai K. Hepatoprotective and antioxidant activity of Murraya Koenigii leaves extract against paracetamol induced hepatotoxicity in Rats. Int J Basic Clin Pharmacol 2017;6:1274-81. 